\title{
Perbedaan Rerata Indeks Cephalic dan Indeks Frontoparietal antara Suku Minangkabau dan Suku Jawa
}

\author{
Gilang Muhammad Fauzan ${ }^{1}$, Citra Manela ${ }^{2}$, Taufik Hidayat ${ }^{3}$
}

\begin{abstract}
Abstrak
Indeks Kefalometris merupakan nilai yang menggambarkan morfologi bentuk kepala manusia. Indeks cephalic dan indeks frontoparietal termasuk dalam indeks kefalometris dan dapat menunjukkan perbedaan suku dan jenis kelamin. Tujuan penelitian ini adalah membandingkan indeks cephalic dan indeks frontoparietal pada laki-laki dan perempuan antara suku Minangkabau dan suku Jawa. Penelitian ini dilakukan dengan metode cross sectional pada 18 laki-laki dan perempuan dari suku Minangkabau dan suku Jawa yang tinggal di Kota Padang, Sumatera Barat. Indeks cephalic dan indeks frontoparietal ditentukan dari perhitungan hasil pengukuran panjang kepala, lebar kepala dan lebar dahi responden. Pada data dilakukan uji normalitas Shapiro-Wilk dan uji t tidak berpasangan untuk melihat perbedaan rerata pada kedua kelompok. Rerata indeks cephalic pada suku Minangkabau adalah 75,98 $\pm 0,77$ untuk perempuan dan 77,41 \pm 1,42 untuk laki-laki. Rerata indeks cephalic pada suku jawa adalah 86,10 $\pm 1,05$ untuk perempuan dan 87,58 \pm 1,52 untuk laki-laki. Rerata indeks frontoparietal pada suku Minangkabau adalah 91,30 $\pm 4,25$ untuk perempuan dan $91,54 \pm$ 4,38 untuk laki-laki. Rerata indeks frontoparietal pada suku jawa adalah 92,02 $\pm 3,23$ untuk perempuan dan 92,04 \pm 2,22 untuk laki-laki. Simpulan studi ini adalah terdapat perbedaan rerata indeks cephalic yang signifikan antara suku Minang dan Suku Jawa, juga terdapat perbedaan yang signifikan antara laki-laki dengan perempuan Minangkabau dan laki-laki dan perempuan Jawa, tetapi tidak terdapat perbedaan rerata indeks frontoparietal yang bermakna pada laki-laki dan perempuan suku Minangkabau dan Jawa.
\end{abstract}

Kata kunci: indeks cephalic, indeks frontoparietal, jenis kelamin, suku

\begin{abstract}
Cephalometric index is a value that describes the morphological shape of human head. Cephalic index and frontoparietal index are included in the cephalometric index. These can show differences in ethnicity and gender. The objective of this study was to compare the cephalic index and the frontoparietal index in men and women between Minangkabau and Java ethnics. The study was conducted by using cross sectional method on 18 men and women from Minangkabau and Java Ethnics who live in Padang city, West Sumatera. Cephalic index and frontoparietal index were determined from the calculation of head length, head width and forehead width measurements from respondents. The data being tested with Shapiro-Wilk normality test and independent $t$-test to see the difference between two groups. The mean of cephalic index in Minangkabau were 75,98 $\pm 0,77$ for women and 77,41 $\pm 1,42$ for men. The mean of cephalic index in Javanese were 86,10 $\pm 1,05$ for women and 87,58 \pm 1,52 for men. The mean of frontoparietal index in Minangkabau were 91,30 \pm 4,25 for women and 91,54 \pm 4,38 for men. The mean of frontoparietal of Javanese were 92,02 \pm 3,23 for women and 92,04 $\pm 2,22$ for men. The conclusion is a significant differences off cephalic index between Minangkabau and Javanese, also there is a significant differences between men and women of Minangkabau ethnic, men and women of Java ethnic, but there is not a significant mean differences of frontoparietal index between men and women on both ethnics.
\end{abstract}

Keywords: cephalic index, frontoparietal index, gender, ethnics 
Affiliasi penulis: 1. Prodi Kedokteran Fakultas Kedokteran Universitas Andalas Padang (FK Unand), 2. Bagian IImu Kedokteran Forensik FK Unand, 3. Bagian IImu Kedokteran Forensik FK Unand Korespondensi: Gilang Muhammad Fauzan, Email: gilangmuhammadf@gmail.com,Telp: 08112298534

\section{PENDAHULUAN}

Antropometri merupakan ilmu yang berkaitan dengan pengukuran bentuk, ukuran, kekuatan, mobilitas dan fleksibilitas serta kapasitas kerja. ${ }^{1}$ Pengukuran dimensi tubuh tersebut meliputi bentuk tubuh, ketebalan kulitm lingkar, panjang, dan lebar dari bagian tubuh tertentu. ${ }^{2}$

Salah satu pemeriksaan yang terdapat di dalam antropometri adalah kefalometri. Pemeriksaan ini merupakan metode pengukuran manusia yang dititik beratkan pada daerah kepala dan wajah manusia. Kefalometri dapat mengindikasikan variasi bentuk manusia pada berbagai suku. Pengamatan variasi bentuk manusia berdasarkan jenis morfologi dapat menentukan nilai indeks kefalometris yang dinamakan titik kefalometris. ${ }^{3}$ Ada beberapa poin yang dinilai didalam indeks kefalometri yaitu ditentukan dari tipe cephalic, tipe facial, tipe nasalis, dan tipe frontoparietal. Berdasarkan tipe tersebut bisa di identifikasikan baik persamaan dan perbedaan yang dimiliki dari suatu suku. ${ }^{4}$ Penelitian yang dilakukan oleh Obaje et al terhadap 75 laki-laki dan 83 orang perempuan suku lgede dan 129 laki-laki dan 138 perempuan suku idoma, Nigeria menunjukkan bahwa terdapat perbedaan dari indeks cephalic antara suku Igede dan suku Idoma, dimana pada suku Igede memiliki indeks cephalic yang lebih kecil (76.54\%) dibandingkan dengan suku Idoma dengan besar indeks cephalic (77.33). ${ }^{5}$

Fadhilah (2012) melakukan penelitian tentang perbandingan indeks cephalic pada laki-laki dewasa yang berasal dari Suku Jawa dan Lampung. Dari hasil yang didapatkan bahwa terdapat perbedaan indeks cephalic suku Lampung (85, 86\%) lebih kecil dibandingkan dengan suku Jawa $(87,41 \%)$ dengan perbedaan rerata indeks keduanya sebesar $1,55 \%{ }^{6}$ Penelitian selanjutnya dilakukan oleh Irsa dan Hon (2013), yang melakukan penelitian terhadap suku Minang, Nias dan Mentawai. Hasil yang didapatkan adalah pada suku Minang memiliki panjang kepala yang lebih panjang, ukuran panjang hidung dan tinggi dagu yang leebih panjang daripada populasi lainnya. Suku Minang dan Mentawai memiliki tipe kepala Mesocephalic, suku Nias adalah Brachicephalic, suku Minang dan Nias memiliki wajah euryprosopic dan tipe frontoparietal lebar pada ketiga suku. ${ }^{4}$

Kota Padang merupakan kota yang menempati pantai barat dari Pulau Sumatera yang sekaligus ibu kota dari Provinsi Sumatera Barat, Indonesia. Dari utara ke selatan, provinsi dengan wilayah seluas 42.297,30 km² ini berbatas dengan empat provinsi yaitu Sumatera Utara, Riau, Jambi dan Bengkulu. Sumatera terbagi menjadi 19 Kota/Kabupaten dan Kota Padang adalah salah satunya. ${ }^{7}$ Jumlah penduduk di Provinsi Sumatera Barat pada tahun 2010 yaitu 4.993.112 jiwa, ${ }^{8}$ dan meningkat menjadi 5.196.289 pada tahun 2015, sehingga Sumatera Barat Memiliki laju pertubuhan penduduk per tahun sebesar $1.04 \%$. Persentase penduduk menurut jenis kelamin yang ada di Sumatera Barat pada tahun 2015 yaitu sebesar $49.73 \%$ untuk jenis kelamin pria dan $50.27 \%$ pada jenis kelamin wanita. ${ }^{7}$

Berbagai macam suku dapat ditemukan di Sumatera Barat. Menurut Badan Pusat Statisika Suku yang mempunyai persentase paling banyak yaitu Suku Minangkabau dengan persentase 88, $35 \%$ diikuti dengan Suku Batak 4, 42\%, Suku Jawa 4, 15\% dan yang terakhir Suku Mentawai 1, 28\%. Hal ini disebabkan karena adanya beberapa daerah di Sumatera Barat yang dijadikan sebagai daerah transmigrasi yang sebagian besar didalamnya terdapat Suku Jawa. ${ }^{7}$

Keanekaragaman suku yang terdapat di Sumatera barat ini merupakan banyaknya ragam genetik suku bangsa. Salah satu metoda untuk menilai dari banyaknya ragam genetik yang ditemukan di Sumatera Barat ini adalah dengan mengukur morfologi manusia. $^{4}$

Pengukuran kranial dapat diukur menggunakan indeks kefalometri yang dimana suku dan jenis kelamin dapat mempengaruhi hasil dari indeks kefalometri. Suku Minangkabau merupakan suku mayoritas yang terdapat di Sumatera Barat dan suku Jawa dengan populasi sebesar 4, 15\% dari jumlah seluruh penduduk di Sumatera Barat. 
Penelitian indeks kefalometris pada suku Minangkabau dan suku Jawa belum pernah dilakukan. Penelitian ini akan membandingkan indeks cephalic dan indeks frontoparietal pada laki-laki maupun perempuan dari suku Minangkabau dan suku Jawa.

Tujuan penelitian ini adalah membandingkan indeks cephalic dan indeks frontoparietal pada laki-laki maupun perempuan antara suku Minangkabau dan Suku Jawa. Indeks frontoparietal dihitung karena belum terdapat penelitian yang sebelumnya yang membandingkan ukuran kefalometris tersebut antara kelompok jenis kelamin maupun suku. Penelitian dilakukan di Kecamatan Padang Timur karena tingkat kepadatan penduduk di Padang Timur mencapai $10.487 \mathrm{~km}^{2}$ dengan jumlah penduduk 85.473 jiwa pada tahun $2016 .^{9}$

\section{METODE}

Penelitian ini menggunakan rancangan observasional analitik dengan cross sectional. Penelitian ini mempelajari bagaimana gambaran perbedaan rerata indeks cephalic dan indeks frontoparietal pada dua kelompok suku dan jenis kelamin yang berbeda pada satu waktu pengukuran. Kelompok suku yang dilakukan observasi pada penelitian ini adalah Minangkabau dan Jawa. Penelitian ini dilakukan setelah mendapat kelayakan etik (ethical clearance) dari Komisi Etik Penelitian Fakultas Kedokteran Universitas Andalas dengan nomor surat 436/KEP/FK/2017.

Studi ini dilakukan di Kecamatan Padang Timur, Kota Padang pada bulan November 2017 sampai Januari 2018. Pengolahan data dilakukan pada bulan Januari 2018. Populasi penelitian adalah masyarakat yang berdomisili di Kota Padang.

Sampel penelitian merupakan sebagian atau wakil populasi yang diteliti. Penentuan besar sampel untuk penelitian ditentukan dengan menggunakan rumus analitik numerik tidak berpasangan. Jumlah sampel minimal yang didapatkan dari rumus tersebut adalah 36 orang. Subjek penelitian adalah 18 orang laki-laki dari kelompok suku Minangkabau, 18 orang laki-laki dari kelompok suku Jawa, 18 perempuan dari suku Minangkabau, 18 orang perempuan dari suku Jawa.

Pengolahan data diubah kedalam bentuk tabel setelah diperoleh dari proses pengumpulan data dan kemudian diolah dengan menggunakan program komputer. Proses analisis statistik terhadap data dilakukan dengan menggunakan komputer. Analisis yang digunakan adalah analisis univariat dan bivariat.

Pada analisis ini dilakukan perhitungan rerata panjang kepala, lebar kepala, lebar minimal frontal, indeks cephalic, indeks frontoparietal serta bentuk kepala pada kelompok suku Minangkabau dan suku Jawa.

Analisis bivariat berguna untuk mengetahui hubungan antara dua variabel, yaitu variabel dependen dan variabel independen. Uji normalitas data digunakan untuk mengetahui penyebaran suatu data saat di distribusi. Uji normalitas data pada penelitian ini menggunakan metode Shapiro-Wilk karena sampel yang digunakan berjumlah kurang dari 50. Data yang dikatakan bertransformasi normal apabila $\mathrm{p}$ yang dihasilkan diatas 0,05 dan dikatakan tidak normal jika nilai p dibawah 0,05

Uji statistik yang digunakan untuk mengetahui perbedaan dan hubungan antara variabel independen dan variabel dependen numerik dua kelompok tidak berpasangan adalah uji $\mathrm{T}$ tidak berpasangan. Uji $\mathrm{T}$ tidak berpasangan dilakukan pada data yang bertransformasi normal dengan varian yang sama ataupun berbeda. Uji T tidak berpasangan merupakan salah satu uji statistik parametrik yang dilakukan dengan tujuan agar hubungan yang ditemukan dalam penelitian dapat diaplikasikan langsung ke populasi karena menghitung nilai yang sebenarnya. ${ }^{10}$ Apabila data didapatkan dengan distribusi yang tidak merata, maka uji statistik digunakan adalah uji Mann-Whitney.

\section{HASIL}

Responden dalam penelitian ini adalah masyarakat yang berdomisili di kota Padang yang berumur 18 - 25 tahun bersuku Minangkabau dan suku Jawa. 
Tabel 1. Distribusi subjek menurut umur dan jenis kelamin

\begin{tabular}{|c|c|c|}
\hline Karakteristik & $\mathbf{n}$ & Persentase (\%) \\
\hline \multicolumn{3}{|l|}{ Umur } \\
\hline 18 & 13 & $17,6 \%$ \\
\hline 19 & 16 & $21,6 \%$ \\
\hline 20 & 10 & $13,5 \%$ \\
\hline 21 & 21 & $28,4 \%$ \\
\hline 22 & 8 & $10,8 \%$ \\
\hline 23 & 3 & $4,1 \%$ \\
\hline 24 & 1 & $1,4 \%$ \\
\hline 25 & 0 & $0 \%$ \\
\hline \multicolumn{3}{|l|}{ Jenis Kelamin } \\
\hline Laki-laki & 36 & $50 \%$ \\
\hline Perempuan & 36 & $50 \%$ \\
\hline
\end{tabular}

Berdasarkan Tabel 1 didapatkan mengenai karakteristik subjek penelitian, mayoritas subjek penelitian ini adalah berusia 21 tahun sebanyak 21 orang $(28,4 \%)$, berusia 19 tahun sebanyak 16 orang $(21,6 \%)$, berusia 18 tahun sebanyak 13 orang $(17,6$ $\%)$, berusia 20 tahun sebanyak 10 orang (13,5\%), berusia 22 tahun sebanyak 8 orang (10,8\%), berusia 23 tahun sebanyak 3 orang $(4,1 \%)$, dan berusia 24 tahun sebanyak 1 orang $(1,4 \%)$. Tabel ini juga menampilkan karakteristik subjek penelitian dengan jenis kelamin laki-laki sebanyak 36 orang (50\%) dan perempuan 36 orang $(50 \%)$.

Tabel 2. Pengukuran subjek indeks cephalic menurut suku dan jenis kelamin

\begin{tabular}{ccccc}
\hline Suku & $\begin{array}{c}\text { Jenis } \\
\text { Kelamin }\end{array}$ & $\begin{array}{c}\mathbf{n} \\
\text { (cm) }\end{array}$ & $\begin{array}{c}\text { Rerata } \\
\text { SD }\end{array}$ \\
\hline Minangkabau & $\mathrm{P}$ & 18 & 75.98 & 0.77 \\
Jawa & $\mathrm{L}$ & 18 & 77.41 & 1.42 \\
& $\mathrm{P}$ & 18 & 86.10 & 1.05 \\
& $\mathrm{~L}$ & 18 & 87.58 & 1.52 \\
\hline
\end{tabular}

Berdasarkan Tabel 2 terlihat 72 subjek yang diteliti, rerata indeks Cephalic pada suku Minangkabau yang berjenis kelamin perempuan yaitu sebesar 75, 98 sentimeter, sedangkan pada jenis kelamin laki-laki sebesar 77, 41 sentimeter. Rerata indeks Cephalic pada suku Jawa yang berjenis kelamin perempuan yaitu sebesar 86,10 sentimeter sedangkan pada jenis kelamin laki- laki sebesar 87,58 sentimeter
Tabel 3. Pengukuran subjek indeks frontoparietal menurut suku dan jenis kelamin

\begin{tabular}{ccccc}
\hline Suku & $\begin{array}{c}\text { Jenis } \\
\text { Kelamin }\end{array}$ & $\mathbf{n}$ & $\begin{array}{c}\text { Rerata } \\
\mathbf{( c m )}\end{array}$ & SD \\
\hline Minangkabau & $\mathrm{P}$ & 18 & 91.30 & 4.25 \\
Jawa & $\mathrm{L}$ & 18 & 91.54 & 4.38 \\
& $\mathrm{P}$ & 18 & 92.02 & 3.23 \\
& $\mathrm{~L}$ & 18 & 92.04 & 2.22 \\
\hline
\end{tabular}

Berdasarkan Tabel 3 terlihat dari 72 subjek yang diteliti, rerata indeks Frontoparietal pada suku Minangkabau yang berjenis kelamin Perempuan yaitu sebesar 91, 30 sentimeter, sedangkan pada jenis kelamin Laki-laki sebesar 91, 54 sentimeter. Rerata indeks Frontoparietal pada suku Jawa yang berjenis kelamin perempuan yaitu sebesar 92, 02 sentimeter sedangkan pada jenis kelamin laki- laki sebesar 92, 04 sentimeter.

Uji normalitas data pada analisis indeks Cephalic suku minang yang berjenis kelamin perempuan didapatkan nilai $p$ sebesar 0.735 dan jenis kelamin laki-laki didapatkan $p$ sebesar 0.865 , sedangkan pada suku Jawa yang berjenis kelamin perempuan didapatkan nilai p sebesar 0.181 dan laki laki didapatkan $\mathrm{p}$ sebesar 0.117 . Pada analisis indeks Frontoparietal suku Minangkabau yang berjenis kelamin perempuan didapatkan nilai $p$ sebesar 0.224 dan jenis kelamin laki-laki didapatkan p sebesar 0.923 , sedangkan pada suku Jawa yang berjenis kelamin perempuan didapatkan nilai $p$ sebesar 0.158 dan laki laki didapatkan $\mathrm{p}$ sebesar 0.286. Berdasarkan uji normalitas data, maka analisis data dilanjutkan dengan melakukan uji statistik parametrik menggunakan Independent T-test.

Tabel 4. Hasil analisis data uji t tidak berpasangan indeks cephalic dan frontoparietal berdasarkan suku

\begin{tabular}{cc}
\hline Indeks Kefalometris & $\mathbf{p}$ \\
\hline Indeks cephalic & 0.000 \\
Indeks Frontoparietal & 0.476
\end{tabular}

Tabel 4 menunjukkan signifikansi Indeks Cephalic dan Indeks Frontoparietal antara suku Minangkabau dan suku Jawa. Hasil analisis data ini 
didapatkan perbedaan yang bermakna $(p<0,05)$ indeks Cephalic antara suku Minangkabau dengan suku Jawa, sedangkan pada analisis indeks Frontoparietal tidak didapatkan hasil yang bermakna antara suku Minangkabau dan suku Jawa.

Tabel 5. Hasil analisis data uji t tidak berpasangan indeks cephalic dan frontoparietal pada suku minangkabau berdasarkan jenis kelamin

\begin{tabular}{cc}
\hline Indeks Kefalometris & $\mathbf{p}$ \\
\hline Indeks cephalic & .001 \\
Indeks Frontoparietal & .896 \\
\hline
\end{tabular}

Tabel 5 menunjukkan signifikansi Indeks Cephalic dan Indeks Froontoparietal pada suku Minangkabau antara jenis kelamin laki-laki dan jenis kelamin perempuan. Hasil analisis didapatkan terdapat perbedaan yang bermakna $(p<0,05)$ indeks Cephalic antara laki laki Minang dengan perempuan Minangkbau, sedangkan pada analisis indeks Frontoparietal tidak didapatkan hasil yang bermakna antara laki laki suku Minangkabau dan Perempuan suku Minangkabau.

Tabel 6. Hasil analisis data uji $\mathrm{t}$ tidak berpasangan indeks cephalic dan frontoparietal pada suku jawa berdasarkan jenis kelamin

\begin{tabular}{cc}
\hline Indeks Kefalometris & $\mathbf{P}$ \\
\hline Indeks cephalic & .002 \\
Indeks Frontoparietal & .981 \\
\hline
\end{tabular}

Tabel 6 menunjukkan signifikansi Indeks Cephalic dan Indeks Froontoparietal pada suku Jawa antara jenis kelamin laki-laki dan jenis kelamin perempuan. Hasil analisis didapatkan terdapat perbedaan yang bermakna $(p<0,05)$ indeks Cephalic antara laki laki Jawa dengan perempuan Jawa, sedangkan pada analisis indeks Frontoparietal tidak didapatkan hasil yang bermakna antara laki laki suku Jawa dan Perempuan suku Jawa.

\section{PEMBAHASAN}

Hasil penelitian menunjukkan bahwa terdapat perbedaan yang signifikan pada Indeks Cephalic antara suku Minangkabau dan suku Jawa dengan nilai $\mathrm{p}=.000$. Hasil penelitian ini sesuai dengan yang dilakukan oleh Sarah pada tahun 2011 yaitu dilakukan terhadap 32 orang Batak $(50 \%)$ dan 32 orang Cina $(50 \%)$, terlihat perbedaan nilai sefalik indeks pada kedua suku tersebut. Pada orang Batak, diperoleh nilai rata-rata sefalik indeks secara keseluruhan yaitu 67,9984 . Sedangkan pada orang Cina, diperoleh nilai ratarata sefalik indeks secara keselurah yaitu 85,5000 dengan nilai $p=0,17$. $^{11}$

Penelitian lain yang berkaitan dengan Indeks Cephalic juga dilakukan oleh Johari pada tahun 2014 dimana Perbandingan nilai rerata lebar kepala, panjang kepala dan indeks sefalik etnik Melayu dan India menunjukkan, rerata lebar kepala etnik Melayu $(153,02 \mathrm{~mm})$, lebih besar dari etnik India (145,82mm) dan menunjukkan perbedaan yang signifikan $(p<0,05)$. Sebaliknya, rerata panjang kepala antara etnik Melayu $(179,17 \mathrm{~mm})$ dan etnik India (178,75mm), menunjukkan tidak ada perbedaan yang signifikan $(p>0,05)$. Sedangkan pada perbandingan indeks cephalic rerata indeks sefalik etnik Melayu $(85,44)$, lebih besar dari etnik India $(81,64)$ dan terdapat perbedaan yang signifikan $(p<0,05)^{(12)}$

Penelitian yang dilakukan oleh Yagain et al (2012) pada populasi di India khususnya di Manipal mendapatkan rata-rata indeks cephalic (79,4\%), dengan presentase bentuk kepala dolicocephalic (31\%), mesocephalic (18\%), brachycephalic (33\%), dan hyperbrachycephalic (13, 9\%). ${ }^{13}$

Brakhisefalisasi dapat didefinisikan sebagai peningkatan lebar kepala relatif terhadap panjang kepala, sehingga akibatnya bentuk kepala ketika dilihat dari arah vertikal tampak semakin membulat. Brakhisefalisasi diamati pertama kali oleh Weidenreich, dengan kesimpulannya bahwa brakhisefalisasi terjadi seiring dengan waktu pada berbagai populasi di dunia. Penelitian pada etnik India telah menunjukkan adanya brakhisefalisasi dari tahun ke tahun dimana awalnya etnik India merupakan ras kaukasoid dengan bentuk kepala mesosefalik. Terjadinya brakhisefalisasi yang seiring waktu menunjukkan bahwa brakhisefalisasi terjadi akibat dari pengaruh evolusi. $^{12}$

Pengukuran Indeks Cephalic yang dilakukan oleh Irsa dan Hon pada tahun 2013 yang melakukan penelitian terhadap suku Minangkabau, Nias dan 
Mentawai menunjukkan bahwa terdapat perbedaan yang signifikan pada ketiga suku tersebut. Pada penelitian yang membandingkan panjang kepala dari setiap suku, suku Minang dan Nias didapatkan nilai $\mathrm{p}=0,049$, sedangkan pada penelitian yang membandingkan suku Minangkabau dan suku Mentawai didapatkan nilai $p=0,019$. Sedangkan pada penelitian yang membandingkan lebar kepala, terdapat perbedaan yang signifikan antara suku Minang dan suku Mentawai dengan p sebesar 0,025. ${ }^{4}$

Penelitian lain pada tahun 2013 oleh Herawaty (2011) yang dilakukan kepada beberapa suku kota Medan dengan jumlah sampel 412 orang (187 laki-laki dan 215 perempuan) didapatkan data bahwa rerata indeks cephalic pada suku Mandailing sebesar $81,80 \%$, suku Aceh $82,55 \%$, suku Karo $82,66 \%$, suku Batak Toba 82, 67\%, dan suku Nias sebesar 86, $28 \%$. $^{14}$

Identifikasi jenis kelamin dari kranial dapat dilakukan pengukuran dengan tingkat akurasi 80-90\%.

Antara karakter tulang pada kepala yang dapat membedakan laki-laki dan perempuan adalah kapasitas kranial, dahi atau tulang frontal, tulang zygomaticus, mandibula, sudut gonion dan dagu atau gnation. $^{15}$

Penelitian Indeks Frontoparietal tidak ditemukan hasil yang signifikan antara suku Minangkabau dan suku Jawa. Penelitian lain yang dilakukan Irsa dan Hon pada suku Nias dan mentawai didapatkan hasil Lebar Minimal Frontal (LMF) yang tidak signifikan yaitu sebesar 0,669, sedangkan pada penelitian Lebar Minimal Frontal pada suku Minangkabau dan Mentawai didapatkan p sebesar 0,05 . Penelitian lain juga dilakukan pada Lebar Byzigomatic (LB) pada suku Minangkabau dan suku Mentawai dengan hasil tidak signifikan yaitu 0,207. ${ }^{4}$

Penelitian lain juga dilakukan oleh Fauziah Lubis pada tahun 2017 ditemukan bahwa lebar dahi laki-laki dan perempuan suku Batak adalah 12,22 dan $12 \mathrm{~cm}$, sedangkan pada pengukuran suku Tionghoa didapatkan hasil yang lebih besar yaitu 12, 86 pada jenis kelamin laki-laki dan 12, $5 \mathrm{~cm}$ pada jenis kelamin wanita sehingga hasil yang didapatkan dari penelitian ini rata-rata bentuk dahi suku-suku di Indonesia adalah lebar atau eurymetopia. Pada penelitian indeks Frontoparietal terhadap dua kelompok jenis kelamin didapatkan $p=0,117$ sehingga dari penilitan tersebut dapat disimpulkan bahwa rerata indeks Frontoparital terhadap jenis kelamin tidak signifikan. ${ }^{16}$

Penelitian yang berkaitan dengan Indeks Frontoparietal dengan jenis kelamin dan suku masih sedikit ditemukan sehingga tidak dapat dibandingkan dengan penelitian lain. Namun, penelitian yang dilakukan oleh Hossain et al pada tahun 2013 didapatkan hasil yang signifikan antara nilai indeks cephalic dan jarak lebar minimal frontalis yaitu $p=0,148$ sehingga hasil dari penelitian tersebut menunjukkan bahwa semakin besar lebar minimal frontalis, maka nilai indeks cephalic akan semakin besar pula dan kepala akan cenderung masuk kedalam klasifikasi brachycephalic. ${ }^{17}$

\section{SIMPULAN}

Terdapat perbedaan bermakna rerata indeks cephalic pada laki-laki dan perempuan suku Minangkabau.

Terdapat perbedaan bermakna rerata indeks cephalic pada laki-laki dan perempuan suku Jawa.

\section{DAFTAR PUSTAKA}

1. Pheasant S, Haslegrave C. Bodyspace: anthropometry, ergonomics and the design of work. Edisi ke-3. International Journal of Nursing Studies. United States: T\&F Informa. 2005; 24: 347-8.

2. Fryar $\mathrm{CD}, \mathrm{Gu} \mathrm{Q}$, Ogden $\mathrm{CL}$. Anthropometric reference data for children and adults: United States, 2007-2010. Vital and health statistics. Series 11, Data from the national health survey. 2012. 1-48. Tersedia dari: http://www.ncbi.nlm.nih. gov/pubmed/25204692

3. Romdhon A. Identifikasi forensik rekonstruktif menggunakan indeks kefalometris. Majority. 2015;4(8):23-8.

4. Irsa R, Hon D. Variasi kefalometri pada beberapa suku di Sumatera Barat (Cephalometry variation of ethnics in West Sumatra). Biol Univ Andalas. 2013;2(2):130-7.

5. Obaje SG, Hamman WO, Ibegbu AO, WaitiehKabehl AK. Study of cephalic indices among benue ethnic groups, Nigeria. Asian J Cell Biol. 2015;10 (1):1-12 
6. Fadhilah A. Perbandingan indeks cephalic dan gambaran bentuk kepala laki-laki dewasa pada suku Lampung dan Jawa di desa Negeri Sakti Provinsi Lampung [skripsi]. Lampung: Universitas Lampung; 2012.

7. Badan Pusat Statistik (BPS) Provinsi Sumatera Barat. Provinsi Sumatera Barat dalam angka. Padang: BPS Provinsi Sumatera Barat; 2016.

8. Badan Pusat Statistik. Kewarganegaraan, suku bangsa, agama, dan bahasa sehari-hari penduduk Indonesia. Hasil Sensus Penduduk 2010. Jakarta: BPS; 2011.

9. Badan Pusat Statistik Kota Padang. Kecamatan Padang Timur dalam Angka. BPS Kota Padang; 2017.

10. Dahlan S. Pintu gerbang memahami statistik, metodologi, dan epidemiologi. Edisi ke-2. Jakarta: Sagung Seto; 2016.

11. Sarah HNG. Pengukuran sefalik indeks etnis Batak dan Cina pada siswa-siswi kelas $X$ dan Kelas XI SMA Swasta Santo Thomas 1 Medan tahun pelajaran 2010-2011 [skripsi]. Medan: Universitas Sumatera Utara; 2011.
12. Johari JB. Studi antropometri menggunakan indeks sefalik pada etnik Melayu dan India mahasiswa Malaysia FKG USU [skripsi]. Medan: Universitas Sumatera Utara; 2014.

13. Yagain VK, Pai SR, Kalthur SG, Chethan P, Hemalatha I. Study of cephalic index in Indian Students. Int J Morphol. 2012;30(1):125-9.

14. Herawati N. Penentuan indeks kepala dan wajah orang Indonesia berdasarkan suku di Kota Medan (tesis). Medan: Universitas Sumatera Utara; 2011.

15. Indriati E. Antropometri untuk kedokteran, keperawatan, gizi dan olahraga. Yogyakarta: PT Intan Sejati; 2010.

16. Lubis F. Perbedaan rerata indeks cephalic dan indeks frontoparietal antara suku Bali dan suku Batak di Kecamatan Tanjung Senang Bandar lampung [skripsi]. Bandar Lampung: Universitas Lampung; 2017.

17. Hossain MG, Saw A, Alam R, Ohtsuki F, Kamarul T. Multiple regression analysis of anthropometric measurements influencing the cephalic index of male Japanese university students. Singapore Med J. 2013;54(9):516-20. 